\title{
AI BASED FINANCIAL SYSTEM: THE WAY FINANCIAL MATRIX DAN BRAILLE INDEX IMPROVE FINANCIAL REPORTING
}

\author{
Tri Junarso \\ PT Wisesa Latih Indonesia
}

\begin{abstract}
Abstrak-Perlu terobosan supaya akuntansi dapat diakses dengan mudah baik oleh akuntan maupun Non Akuntan. Penulis terinspirasi bagaimana seorang tunanetra mampu membaca, padahal mereka tidak dapat melihat apappun karena buta. Dengan huruf Braille, mata mereka "dijembatani" untuk membaca atau menulis.

AI based accounting adalah sistem akuntansi yang memiliki senyawa kecerdasan buatan (artificial intelligence), yang dapat dioperasikan di segala waktu, cuaca dan tempat karena tersambung pada internet. Dengan AI, sistem akuntansi ini dilengkapi algoritma dan pemrograman yang memungkinkan seorang yang buta akuntansi dapat berprestasi seperti akuntan profesional. Akuntan pada level itu, biasanya mampu melakukan pembukuan dengan baik dan menerbitkan laporan keuangan. Dalam hal AI based accounting, pembukuan dan laporan keuangan telah di-preset (atur sebelumnya), baik kode pembukuan (GL code) maupun tabulasi untuk laporan financial statement.
\end{abstract}

Kata Kunci : AI, laporan financial

\section{Pendahuluan}

Pada tahun 1851 tulisan Braille diajukan pada pemerintah negara Perancis agar diakui secara sah oleh pemerintah. Sejak saat itu penggunaan huruf Braille mulai berkembang luas hingga mencapai negara-negara lain. Pada akhir abad ke-19 sistem tulisan ini diakui secara universal dan diberi nama 'tulisan Braille'. Sistem tulisan Braille mencapai kesempurnaannya pada tahun 1834. Huruf-huruf Braille tersebut menggunakan konsep penulisannya seperti kartu domino.

Dalam era digital sekarang ini Samsung telah membuat gebrakan besar dalam bidang komunikasi untuk kaum tunanetra di era komputerisasi dengan ide briliannya yang mengaplikasikan touch pad berhuruf Braille pada telepon genggam. Perusahaan inipun berhasil menyabet penghargaan tertinggi Gold Award pada forum IDEA: Industrial Design Excellence Award di bulan Agustus 2006. [1]

Akunting pun, mengalami perjalanan sejarah seperti huruf Braille, sampai detik ini masih merupakan pekerjaan yang relatif rumit (complicated) bagi internal akuntan perusahaan, apalagi non akuntan. Maka sebagian besar perusahaan memastikan kebenaran laporan keuangannya dengan cara diaudit oleh akuntan publik sebagai validasi.

Karena rumit dipahami oleh non akuntan, penulis terinspirasi oleh bagaimana huruf Braille dipakai untuk menuntun para tunanetra membaca, dapat dipergunakan dalam transaksi keuangan. Sehingga transasksi tersebut dapat dilakukan dengan mudah, kesalahan pembukuan dapat diminimalisasi (atau dihindari sama sekali), serta laporan keuangan dapat diterbitkan sewaktu-waktu.

AI (Artificial Intelligence) didefinisikan sebagai perangkat atau sistem yang merasakan lingkungannya dan mengambil tindakan untuk mencapai tujuan. Bapak Artificial Intelligence, John McCarthy, mengatakan AI adalah sains dan teknik membuat mesin cerdas, dalam artikel ini adalah program komputer cerdas. AI tidak hanya tentang robot berpikir dan berperilaku seperti manusia, lebih dari itu AI adalah cara membuat komputer, robot yang dikendalikan komputer, atau perangkat lunak berpikir cerdas, dengan cara yang sama seperti yang dipikirkan dan berperilaku manusia cerdas. [2] 
Perbedaan antara akuntansi konvensional dan AI based accounting adalah

\begin{tabular}{llll}
\multicolumn{1}{c}{$\begin{array}{l}\text { Item } \\
\text { Group }\end{array}$} & \multicolumn{2}{c}{ AI Based Accounting } & \multicolumn{1}{c}{$\begin{array}{c}\text { Conventional Accounting } \\
\end{array}$} \\
\cline { 2 - 3 } & \multicolumn{1}{c}{ Account } & GRouP & Tidak ada \\
& \multicolumn{1}{c}{ Assets } & Debit & \\
Trial Balance & Credit & \\
Error & Tidak perlu & Nol/minimum & Ada \\
Error check & Financial Matrix & Ada \\
GL Account & Integrated & Trial Balance \\
Entry & Multi Entry & Individual \\
Audit & Sedikit/Tidak perlu & Double Entry \\
Error Index & Brailler Index & Perlu \\
Kelebihan AI based accounting di atas memberi banyak keuntungan bagi industri, \\
sehingga sistem baru ini akan menjadi pilihan bijaksana di masa depan.
\end{tabular}

Penulis telah membuat prototype program akuntansi berbasis AI (AI Based Accounting), dengan tujuan untuk lebih "memanusiakan" akuntasi bagi Non Accountant.

\section{Tinjauan Pustaka}

\subsection{ACCOUNTING PRINCIPLE}

Prinsip akuntansi berbeda dari suatu negara dan negara lainnya. Dalam hal IFRS (International Financial Reporting Standards) mencakup berbagai kegiatan akuntansi, tiga diantaranya: [3]

a. Pernyataan Posisi Keuangan (Statement of Financial Position) - atau biasa dikenal sebagai neraca.

b. Pernyataan Penghasilan Komprehensif (Statement of Comprehensive Income): Ini dapat berbentuk satu pernyataan, atau dapat dipisahkan menjadi laporan untung dan rugi serta pernyataan pendapatan lain.

c. Pernyataan Perubahan Ekuitas (Statement of Changes in Equity): Juga dikenal sebagai pernyataan saldo laba untuk periode keuangan yang diberikan.

Perbedaan implementasi standar akuntansi ini, membuka ruang bagi kita berinovasi, terutama dalam era digital sekarang, dan bagaimana AI (artificial inteligence) dapat mengambil peran untuk otomatisasi dan memberi kemudahan bagi masyarakat, baik akuntan maupun non akuntan. Hasilnya mungkin tidak memuaskan semua pihak, terutama para akuntan, karena "merubah" paradigma yang selama ini berjalan. Perubahan tersebut misalnya

i. $\quad$ Pengelompokan Debit dan Kredit (Debit and Credit Grouping)

Untuk penyederhanaan (simplicity) transaksi yang mengakibatkan bertambahnya jumlah uang dalam suatu akun (account) dikelompokkan sesuai dengan sifatnya, misal (Fig. 2)

i.1 Assets dan Expenses dikelompokkan sebagai Debit - karena bertambahnya nilai komulatif akibat naiknya Debit

i.2 Liabilities, Equity dan Revenue dikelompokkan sebagai Kredit (Credit) - karena bertambahnya nilai komulatif akibat naiknya Kredit 
Fig. 2

\begin{tabular}{|c|c|}
\hline ACCOUNT & GROUP \\
\hline Assets & Debit \\
\hline Expenses & Debit \\
\hline Liabilities & Credit \\
\hline Equity & Credit \\
\hline Revenue & Credit \\
\hline
\end{tabular}

ii. Jurnal Transaksi Internal Debit (Internal Debit Journal)

Transaksi Internal Debit (Assets dan Expenses) dibukukan pada satu tempat, yakni Debit saja, dengan menambahkan (+) dan (-). Model ini sudah dipakai akuntan tertentu. (Fig. 3)

Fig. 3

\begin{tabular}{|cccccc}
\hline \multicolumn{1}{|c}{ Internal Debit } & Activity & $\begin{array}{c}\text { Transaction } \\
\text { Code }\end{array}$ & Type & DEBIT & CREDIT \\
Asset - Bank/Cash at Bank (1110100000000000) & Withdraw & 11 & - & -13.000 .000 & \\
& & 11 & + & 13.000 .000
\end{tabular}

iii. Jurnal Internal Kredit (Internal Credit Journal)

Transaksi Internal Kredit (Liabilities, Equity, dan Revenue) dibukukan pada satu tempat, yakni Kredit saja, dengan menambahkan (+) dan (-). Model ini sudah dipakai akuntan tertentu. (Fig. 4)

Fig. 4

\begin{tabular}{lccccc}
\multicolumn{1}{|c}{ Internal Credit } & Activity & $\begin{array}{c}\text { Transaction } \\
\text { Code }\end{array}$ & Type & DEBiT & CREDIT \\
Liability - Third Party Accounts $(12250000000000$ & Withdraw & 12 & - & -2.500 .000 \\
$\begin{array}{l}\text { Liability - Third Party Accounts } \\
(122500000000000)\end{array}$ & Collection & 12 & + & 2.500 .000
\end{tabular}

iv. Jurnal Transaksi Kredit - Debit lunas/pascabayar (CREDIT-DEBIT Paid Transaction Journal)

Umumnya transaksi ini disebut double entry transaction, dan terjadi pada akun Revenue dan Assets, atau Equity dan Assets. Karena itu outcomenya disebut double entry journal. Transaksi ini biasa dilakukan pada pembayaran lunas/pascabayar. (Fig. 5)

Fig. 5

\begin{tabular}{cccccc}
\hline Credit - Debit Paid Transaction & Activity & $\begin{array}{c}\text { Transaction } \\
\text { Code }\end{array}$ & Type & DEBIT & CREDIT \\
Revenue - Product 1 $(2144000000000000)$ & Sales & 5 & + & & 150.000 .000 \\
Asset - Bank/Cash at Bank $(1110100000000$ & Transfer & 5 & + & 150.000 .000 &
\end{tabular}

v. Jurnal Double Entry dalam transaksi Debit - Debit lunas/pascabayar (DebitDebit Paid Transaction Journal) 
Transaksi ini juga disebut double entry transaction, dan terjadi pada akun Expenses dan Assets. Karena itu outcomenya disebut pula sebagai double entry journal. Transaksi ini biasa dilakukan pada pembayaran lunas/pascabayar.

Dalam akuntansi standar tidak dikenal istilah Debit-Debit transaction, kecuali Debit-Credit Transaction. Namun demi memberi ruang bagi non accountant untuk berkiprah dalam akuntansi, maka dibutuhkan inovasi. Inovasi ini tidak merubah prinsip dasar akuntansi pada IFRS maupun GAAP. (Fig. 6)

Fig. 6

\begin{tabular}{cccccc}
\hline Debit - Debit Paid Transaction & Activity & $\begin{array}{c}\text { Transaction } \\
\text { Code }\end{array}$ & Type & DEBIT & CREDIT \\
Expense - Salaries and Wages Expense $(22726000006$ & Payment & 26 & + & 6.000 .000 \\
Asset - Bank/Cash at Bank (1110100000000 & Transfer & 26 & + & 6.000 .000
\end{tabular}

vi. Jurnal Quadruple Entry dalam transaksi dengan pembayaran Cek (Term Payment Transaction Journal)

Dalam akuntansi hanya dikenal double entry, dan tidak muncul istilah multi entry ataupun quadruple entry. Namun demi memberi ruang bagi non accountant untuk berkiprah dalam akuntansi, maka dibutuhkan inovasi. Inovasi ini pun tidak merubah prinsip dasar akuntansi pada IFRS maupun GAAP.

Umumnya laporan keuangan hanya memunculkan Expenses dan Liabilities untuk transaksi dengan pembayaran cek. Dengan inovasi di bawah, transaksi pada Assets (Bank) ditampilkan sebagai "reserve" - dalam bentuk hutang. (Fig. 7)

Sistem akan memberi "alert" bilamana tempo pembayaran terlampaui.

Fig. 7

\begin{tabular}{lccccc} 
Debit - Credit Term Payment Transaction & Activity & $\begin{array}{c}\text { Transaction } \\
\text { Code }\end{array}$ & Type & DEBIT & CREDIT \\
\hline Expense - Cost Of Goods Sold (2251000000000000) & Purchase & 45 & + & 21.000 .000 & \\
Liability - Accounts Payable (1220100000000000) & Payable & 45 & + & & 21.000 .000 \\
& $\begin{array}{l}\text { Cheque } \\
\text { Payment }\end{array}$ & 45 & - & -21.000 .000 & \\
Asset - Cash (1110200000000000) & Reserve & 45 & + & 21.000 .000 & \\
$\quad \begin{array}{l}\text { Bank/Cash at Bank - Reserve (Contra Account) } \\
(1110130000000000)\end{array}$ & & &
\end{tabular}

vii. Jurnal Quadruple Entry dalam transaksi prabayar (Debit - Debit Prepaid Transaction Journal)

Sekali lagi dalam akuntansi hanya dikenal double entry, dan tidak ada istilah multi entry maupun quadruple entry. Namun demi memberi ruang bagi non accountant untuk berkiprah dalam akuntansi, maka dibutuhkan inovasi. Inovasi ini pun tidak merubah prinsip dasar akuntansi pada IFRS maupun GAAP. Dalam hal transaksi Debit - Debit prabayar, akuntansi standar biasanya hanya mencantumkan Expenses dan Assets (Prepaid Expense). Dengan inovasi di bawah, transaksi pada Assets (Bank) ditampilkan sebagai "transfer", dan penambahan Equity ditampilkan sebagai "record.” (Fig. 8) 
Fig. 8

\begin{tabular}{|c|c|c|c|c|c|}
\hline Debit - Debit Prepaid Transaction & Activity & $\begin{array}{c}\text { Transaction } \\
\text { Code }\end{array}$ & Type & DEBIT & CREDIT \\
\hline Expense - Insurance Expense (2272200000000000) & Payment & 3 & + & 10.000 .000 & \\
\hline Equity - Special Accounts (3000000000000000) & Record & 3 & + & & 10.000 .000 \\
\hline Asset - Bank/Cash at Bank (1110100000000000) & Transfer & 3 & - & 10.000 .000 & \\
\hline Asset - Prepaid Expense (1113000000000000) & Record & 3 & + & 10.000 .000 & \\
\hline
\end{tabular}

viii. Jurnal Quadruple Entry dalam transaksi prabayar (Credit - Debit Prepaid Transaction Journal)

Sekali lagi dalam akuntansi hanya dikenal double entry, dan tidak ada istilah multi entry maupun quadruple entry. Namun demi memberi ruang bagi non accountant untuk berkiprah dalam akuntansi, maka dibutuhkan inovasi. Inovasi ini pun tidak merubah prinsip dasar akuntansi pada IFRS maupun GAAP. Dalam hal transaksi Credit Debit prabayar, akuntansi standar biasanya hanya mencantumkan Revenue dan Liability (Unearned Payable). Dengan inovasi di bawah, transaksi pada Assets (Bank) ditampilkan sebagai "transfer", dan penambahan Assets (Prepaid Income) ditampilkan sebagai "record." (Fig. 9) Sistem akan mengeluarkan "alert", bilamana perlu, ketika tempo penyerahan barang atau jasa terlampaui.

Fig. 9

\begin{tabular}{|c|c|c|c|c|c|}
\hline Credit - Debit Prepaid Transaction & Activity & $\begin{array}{l}\text { Transaction } \\
\text { Code }\end{array}$ & Type & DEBIT & CREDIT \\
\hline Revenue - Service 1 (2146000000000000) & Sales & 52 & + & & 610.000 .000 \\
\hline $\begin{array}{l}\text { Liability - Unearned Revenue } \\
(1220900000000000)\end{array}$ & Record & 52 & + & & 610.000 .000 \\
\hline Asset - Bank/Cash at Bank (1110100000000000) & Transfer & 52 & + & 610.000 .000 & \\
\hline Asset - Prepaid Income (1111000000000000) & Record & 52 & + & 610.000 .000 & \\
\hline
\end{tabular}

\section{ROLE OF AI IN FINANCIAL TRANSACTIONS}

AI tidak mengambil alih kompetensi manusia, karena AI dikembangkan oleh manusia. Sebagai pengembang program dengan AI sebagai basisnya, manusia memiliki keunggulan pada problem solving, development dan innovation. Selain itu manusia juga dikaruniai karakter.

Dalam hal akuntansi, AI bertujuan untuk menyederhanakan (simplify), mempercepat (accelerate) dan meminimalisasi kesalahan (error prevention). Program ini akan berjalan jika memenuhi setidaknya dua syarat, yakni penyiapan trial balance, serta membuat GL account yang saling mengaktivasi, mirip kartu domino.

\subsection{Financial Matrix}

Secara umum, neraca saldo (trial balance) bertujuan untuk memastikan bahwa setiap entri debet tercatat, sekaligus entri kredit pun telah dimasukkan dalam pembukuan sesuai dengan prinsip akuntansi entri ganda (double entry).

Penulis memandang Financial Matrix adalah konfigurasi yang menggambarkan transaksi keuangan dalam Debit dan Credit. [4] 
Debit adalah transaksi yang terjadi pada Assets dan Expenses. Sedang Credit adalah transaksi yang dilakukan pada Liabilities, Equity dan Revenue.

Financial Matrix dipergunakan sebagai sarana untuk memastikan akurasi sebuah transaksi sehingga rangkaian GL account yang disepakati telah dibuat dengan benar. Jika penempatan akun (GL account) salah, otomatis akan mengakibatkan ketidakseimbangan dalam neraca. Ketidakseimbangan neraca akan muncul pada "Deviation".

Salah dan benar pada konfigurasi transaksi dalam Financial Matrix akan menghasilkan Braille Index.

Braille Index sama dengan "0" bila "Deviation" terjadi. Artinya konfigurasi akun Salah. Sebaliknya Braille Index sama dengan "1" bila "Deviation" tidak terjadi. Artinya konfigurasi akun Benar. (Fig. 10)

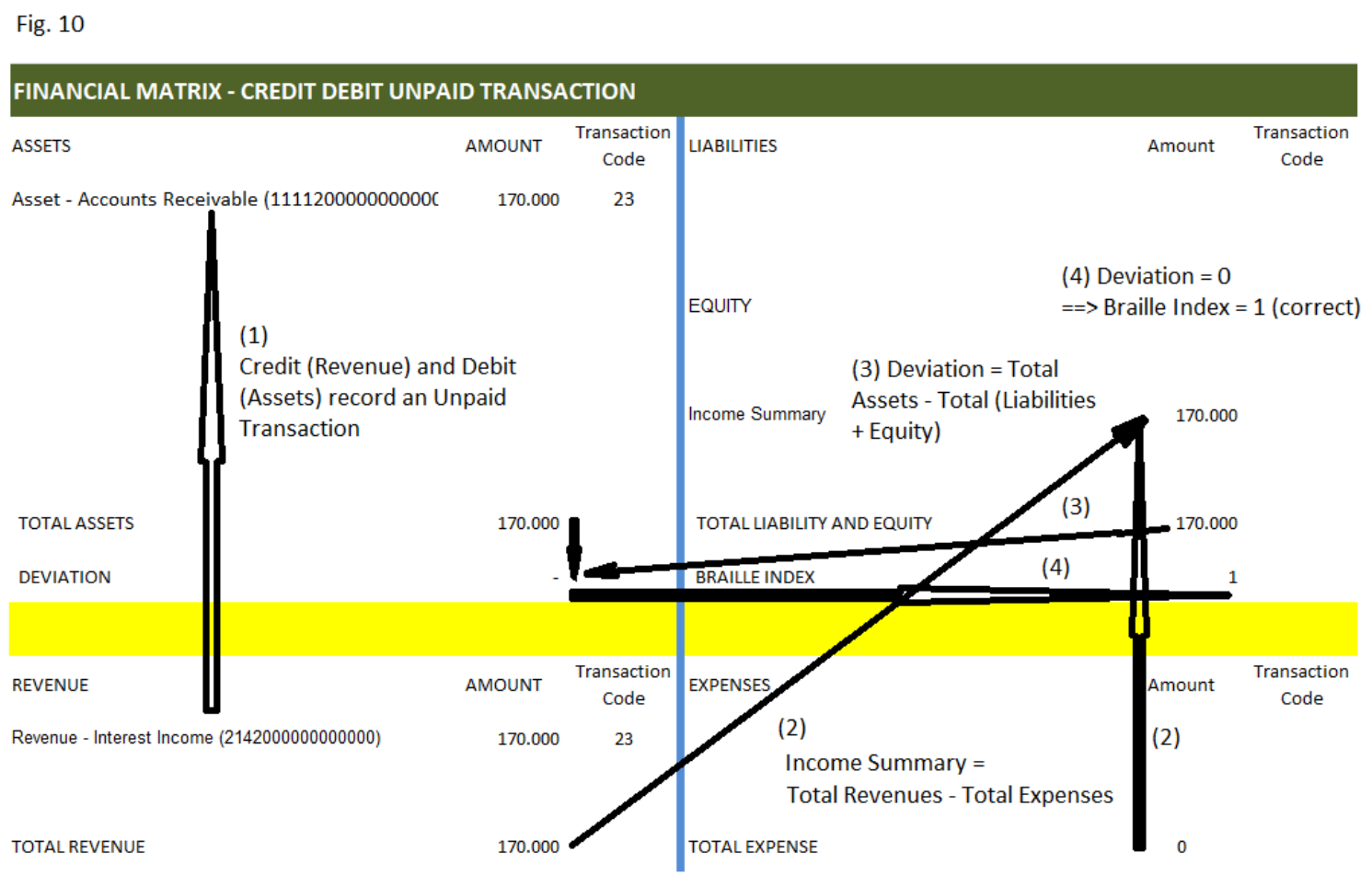

Mula-mula dibuatlah Financial Matrix, mirip neraca yang sebenarnya, berisi Assets, Liabilities, Equity, Revenues, dan Expenses. Ditambahkan dari empat komponen tersebut adalah Income Summary, Deviation dan Braille Index.

Lalu ditetapkan GL Account dan Transaction Code yang terlibat dalam sebuah transaksi. Masukkan transaksi tersebut pada kolom sesuai peruntukannya, misal Debit - Assets \& Expenses, atau Credit - Revenues, Liabilities \& Equity.

Jika hasil akhir pada Total Asset dan Total Liability + Equity jumlahnya sama, maka Deviation $=0$. Sehingga dapat dipastikan GL Account sudah benar, serta dipergunakan sebagai referensi untuk transaksi.

Untuk memudahkan proses pembukuan dan pelaporan, biasanya dituangkan pada sebuah aplikasi accounting.

Tidak seperti akuntansi konvensional, dengan program accounting berbasis AI, laporan dalam bentuk trial balance, untuk memastikan kebenaran transaksi keuangan, tidak diperlukan lagi.

Karenanya sistem ini dapat mengurangi waktu dan biaya, serta mempercepat pengambilan keputusan. 


\subsection{Transaction Form}

Setelah yakin bahwa transaksi dalam trial balance benchmark sudah benar, maka GL account yang dipakai, dicatatkan pada "Form" yang berfungsi sebagai lembaran bukti transaksi, untuk kemudian dilakukan pemrograman.

3.3.Internal Debit Paid Transaction

Contoh dari Internal Debit Paid Transaction adalah transaksi internal di dalam Assets, antara Bank/Cash at Bank dan Cash on Hand. Pada tahap awal, dibuatlah benchmark untuk Financial Matrix, dimana GL account dan GL Title di-entry dalam Assets, lengkap dengan jumlah (Amount) dan Transaction Code-nya.

Jika nilai "Deviation" $=0$, maka konfigurasi akun dalam Financial Matrix tersebut sudah benar, index nya "1"(Fig. 11)

Kemudian dibuat "Form", misal namanya "Petty Cash Request Form," dimana konfigurasi GL code-nya telah di-preset. (Fig. 12)

\begin{tabular}{|c|c|c|c|c|c|}
\hline \multicolumn{6}{|c|}{ FINANCIAL MATRIX - INTERNAL DEBIT PAID TRANSACTION } \\
\hline ASSETS & AMOUNT & $\begin{array}{c}\text { Transaction } \\
\text { Code }\end{array}$ & LIABILITIES & AMOUNT & $\begin{array}{l}\text { Transaction } \\
\text { Code }\end{array}$ \\
\hline Asset - Bank/Cash at Bank (1110100000000000) . & 13.000 .000 & 11 & & & \\
\hline \multirow[t]{3}{*}{ Asset - Cash on Hand (1110200000000 } & 13.000 .000 & 11 & & & \\
\hline & & & EQUITY & & \\
\hline & & & Income Summary & 0 & \\
\hline TOTAL ASSET & 0 & & TOTAL LIABILITY AND EQUITY & 0 & \\
\hline DEVIATION & 0 & & BRAILLE INDEX & 1 & \\
\hline REVENUES & AMOUNT & $\begin{array}{l}\text { Transaction } \\
\text { Code }\end{array}$ & EXPENSES & AMOUNT & $\begin{array}{l}\text { Transaction } \\
\text { Code }\end{array}$ \\
\hline TOTAL REVENUE & 0 & & TOTAL EXPENSE & 0 & \\
\hline
\end{tabular}


Fig. 12

PETTY CASH REQUEST

\begin{tabular}{|c|c|c|c|c|c|c|}
\hline Form & automatical & & & & & \\
\hline \multirow{2}{*}{\multicolumn{2}{|c|}{ Petty Cash Request No. }} & automatical & Current & (type) & Status & select \\
\hline & & & & & & (Prepaid, Paid, Unpaid) \\
\hline \multicolumn{2}{|c|}{ Transaction Keyword } & select & & Transaction Code & & automatical \\
\hline \multicolumn{2}{|c|}{ GL Title 1, GL Code 1} & select & & Amount & & type \\
\hline \multicolumn{2}{|c|}{ GL Title 2, GL Code 2} & automatical & & Amount & & automatical \\
\hline \multicolumn{2}{|c|}{ GL Title 3 , GL Code 3} & automatical & & Amount & & automatical \\
\hline \multicolumn{2}{|c|}{ GL Title 4, GL Code 4} & automatical & & Amount & & automatical \\
\hline
\end{tabular}

\subsection{Internal Credit Paid Transaction}

Transaksi internal kredit pasca bayar (paid transaction) biasanya dilakukan pada "Revenue, Liability dan Equity." Contoh konkritnya adalah transaksi yang melibatkan pihak ketiga dalam bentuk deposit dan withdrawal, seperti berlaku umum dalam perbankan. (Fig. 13)

Dalam hal ini form yang dipakai adalah "Saving Form" atau "Withdrawal Form" Fig. 13

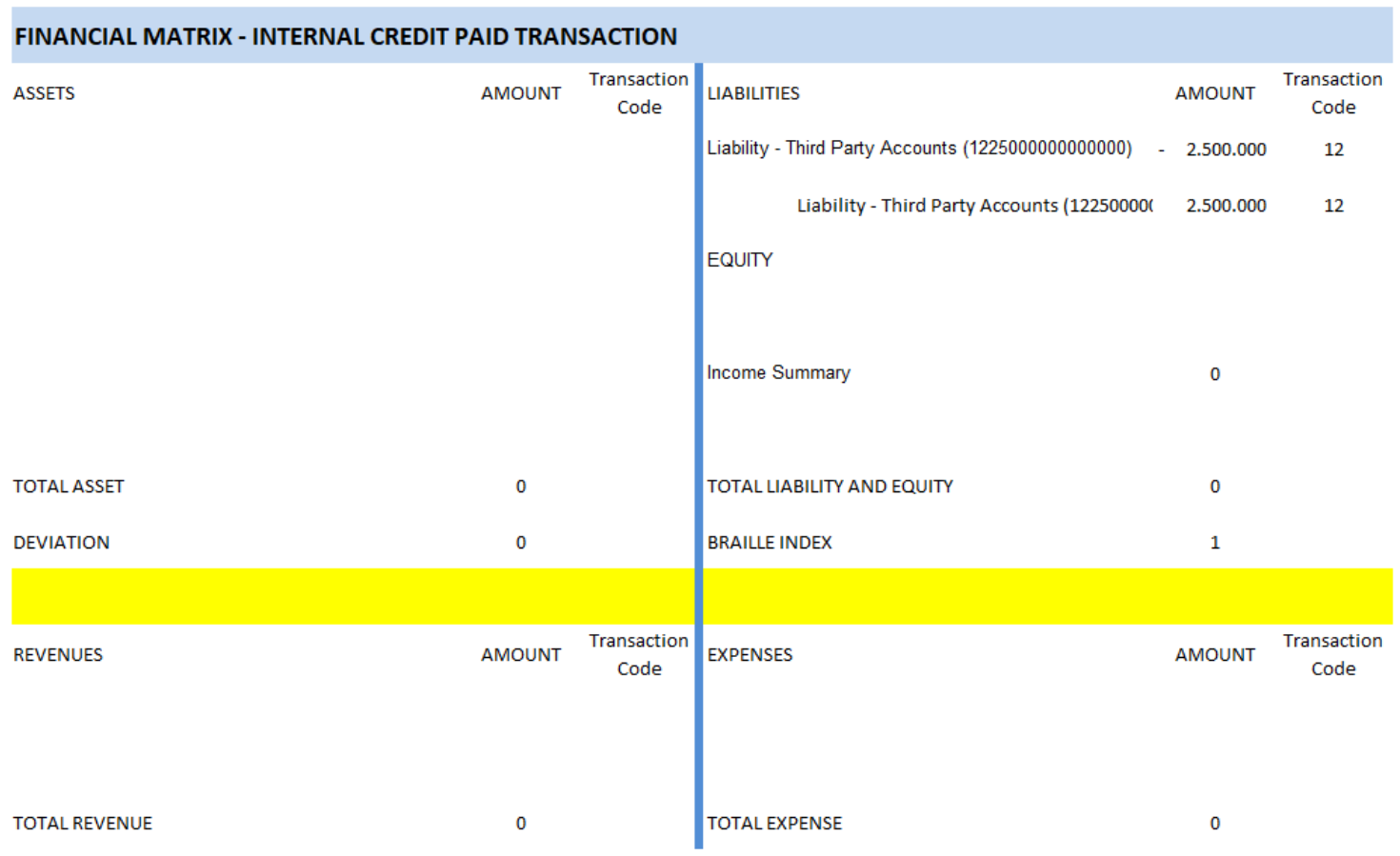

\subsection{Credit-Debit Paid Transaction}

Transaksi Credit-Debit pascabayar dapat dilakukan pada konfigurasi "RevenueAssets." Contohnya adalah transaksi yang muncul tatkala bisnis telah menjual barang 
dan jasanya, dan tunai setelah barang atau jasa tersebut diterima oleh pelanggan. (Fig. 14)

Dalam hal ini form yang dipakai adalah "Sales Record"

\begin{tabular}{|c|c|c|c|c|c|}
\hline \multicolumn{6}{|c|}{ FINANCIAL MATRIX - CREDIT DEBIT PAID TRANSACTION } \\
\hline ASSETS & AMOUNT & $\begin{array}{c}\text { Transaction } \\
\text { Code }\end{array}$ & LIABILITIES & Amount & $\begin{array}{c}\text { Transaction } \\
\text { Code }\end{array}$ \\
\hline \multirow[t]{4}{*}{ Asset - Bank/Cash at Bank (1110100000000000) } & 150.000 .000 & 5 & & & \\
\hline & & & EQUITY & & \\
\hline & & & Income Summary & 150.000 .000 & \\
\hline & 150.000 .000 & & TOTAL LIABILITIES AND EQUITY & 150.000 .000 & \\
\hline DEVIATION & - & & BRAILLE INDEX & 1 & \\
\hline REVENUE & AMOUNT & $\begin{array}{c}\text { Transaction } \\
\text { Code }\end{array}$ & EXPENSES & Amount & $\begin{array}{c}\text { Transaction } \\
\text { Code }\end{array}$ \\
\hline Revenue - Product $1(2144000000000000)$ & 150.000 .000 & 5 & & & \\
\hline TOTAL REVENUE & 150.000 .000 & & TOTAL EXPENSE & 0 & \\
\hline
\end{tabular}

\subsection{Debit-Debit Paid Transaction}

Transaksi Debit-Debit pascabayar (paid transaction) dilakukan pada "Expenses dan Assets (Bank)." Contoh sederhananya adalah perusahaan membeli barang atau jasa pada vendor, dan dibayar setelah barang atau jasa tersebut diterima. (Fig. 15)

Dalam hal ini form yang dipakai adalah "Payment Request Form" 


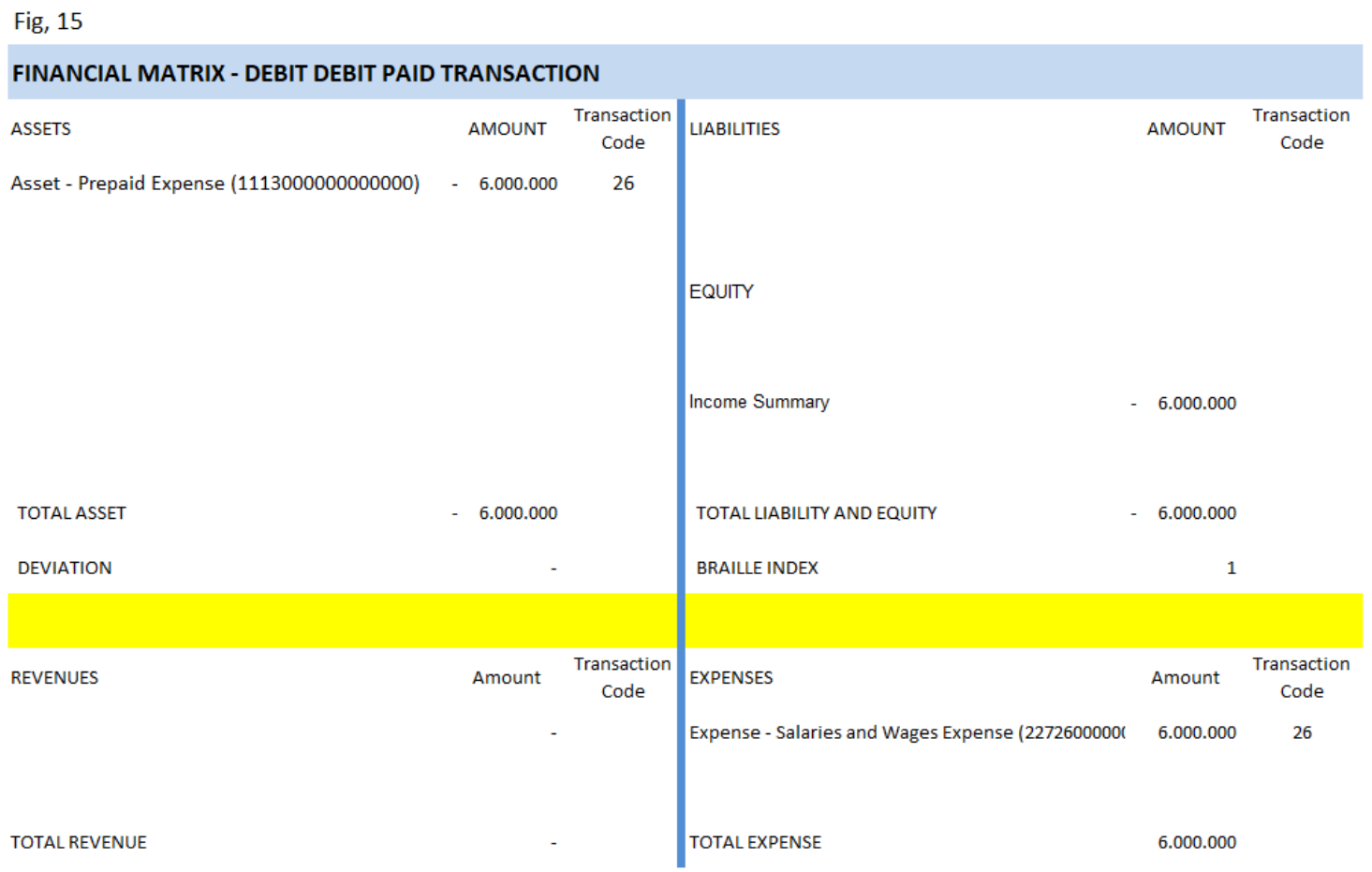

\subsection{Debit-Credit Unpaid Transaction}

Transaksi Debit-Credit pada pembayaran mundur (unpaid transaction) biasanya dilakukan pada "Expenses dan Assets (Bank)." Namun karena status pembayarannya adalah "unpaid", maka menimbulkan hutang/kewajiban (dalam Liabilities). Gambaran konkritnya adalah perusahaan membeli barang atau jasa pada vendor, dan dibayar setelah barang atau jasa tersebut belum dibayar sama sekali. (Fig. 16)

Dalam hal ini form yang dipakai adalah "Payment Request Form" (Unpaid)

Fig. 16

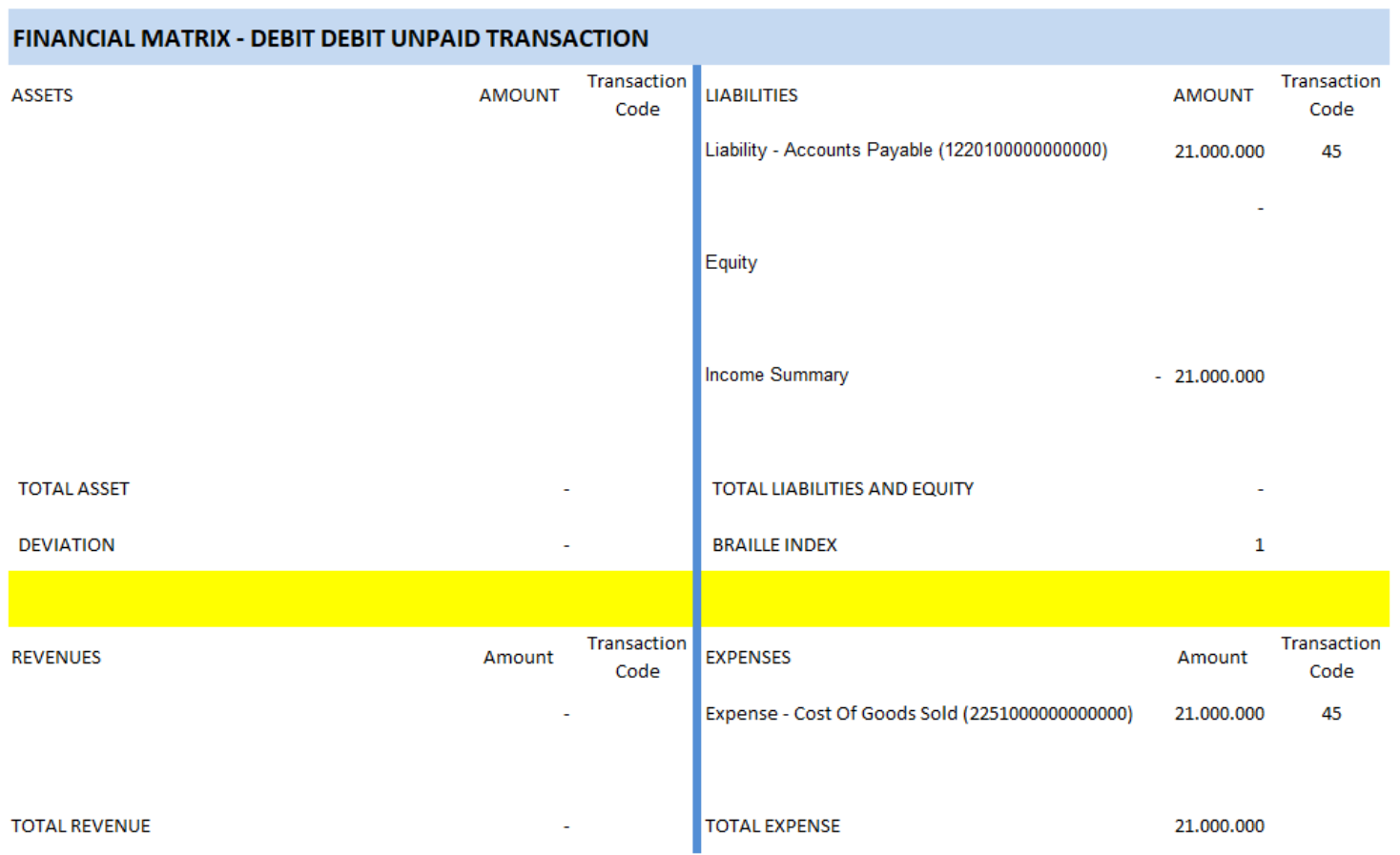




\subsection{Debit-Debit Prepaid Transaction}

Transaksi Debit-Debit prabayar (Debit-Debit prepaid transaction), tanda jadi ataupun uang muka (down payment) sering dilakukan pada "Expenses dan Assets (Bank)." Namun karena status pembayarannya adalah "prepaid", maka menimbulkan "piutang" (dalam Assets). Equity pun seolah-olah mencatat penambahan sementara, yang disimpan dalam "Special Account/Reserve."

Situasi konkritnya adalah perusahaan membeli barang atau jasa pada vendor, yang harus dibayar sebelum barang atau jasa tersebut diterima, misal asuransi, uang muka untuk kendaraan. (Fig. 17)

Dalam hal ini form yang dipakai adalah "Payment Request Form" (Prepaid)

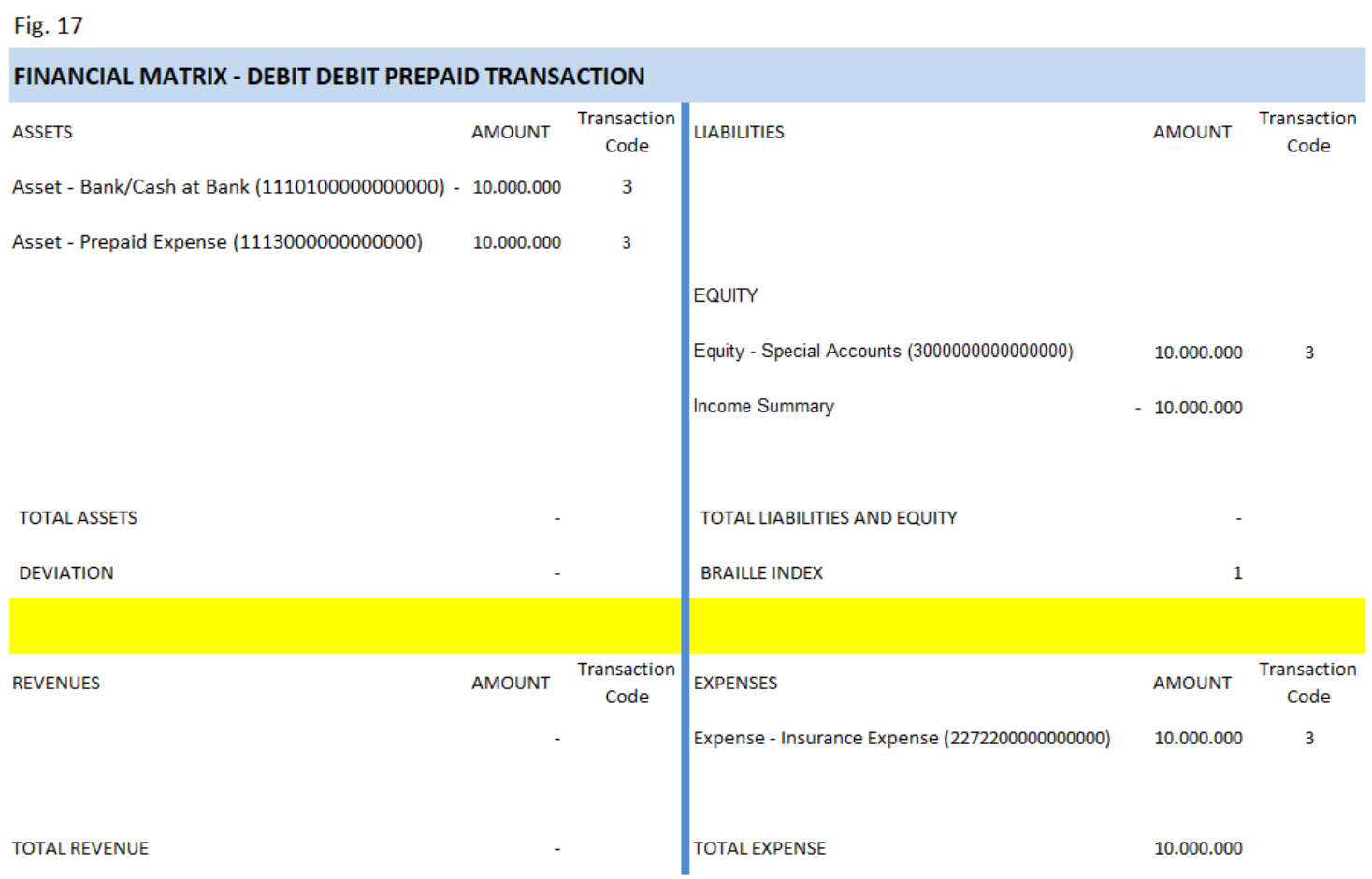

\subsection{Credit-Debit Prepaid Transaction}

Transaksi Credit-DEbit prabayar (Credit-Debit prepaid transaction), tanda jadi ataupun uang muka (down payment) sering dilakukan pada "Revenues dan Assets (Bank)." Namun karena status pembayarannya adalah "prepaid", maka menimbulkan "hutang" dalam Liabilities (Unearned Payable). Assets pun seolah-olah mencatat penambahan nilai sementara, yang disimpan dalam "Assets-Prepaid Income."

Situasi konkritnya adalah perusahaan menjual barang atau jasa pada pelanggan, yang harus dibayar sebelum barang atau jasa tersebut diterima, misal online purchase, atau uang muka untuk kendaraan. (Fig. 18)

Dalam hal ini form yang dipakai adalah "Sales Record” (Prepaid) 


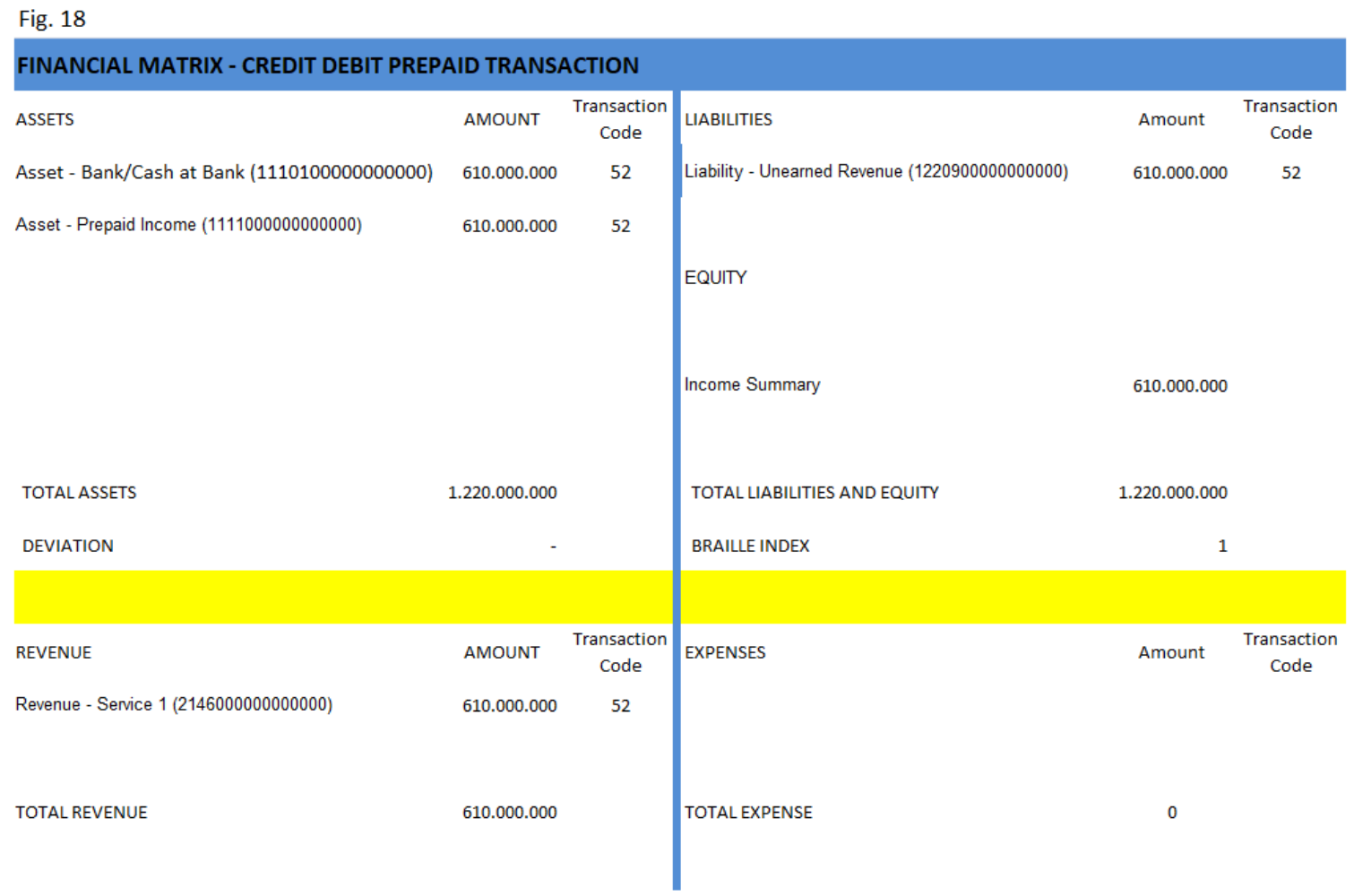

\section{KesimpUlan}

IFRS dan GAAP memberi ruang untuk penyesuaian kepada negara-negara/organisasi pemakainya. Selain itu kedua standar ini membuka diri untuk inovasi sistem akuntansi, sehingga dari waktu ke waktu sistem akuntansi berkembang sesuai jamannya.

AI based accounting system yang mempergunakan Financial Matrix dan Braille Index ini memanfaatkan ruang inovasi yang disediakan oleh IFRS dan GAAP. Sistem ini tidak merubah prinsip-prinsip dasar akuntansi, namun melakukan modifikasi pada beberapa konsep, yang memungkinkan Non Accountant dapat mengoperasikannya dengan mudah, tanpa khawatir salah dalam pembukuan. Sehingga tidak perlu membuat pemeriksaan ulang yang rumit, yang pada akhirnya akan menghemat biaya dan waktu.

Dengan sistem ini, jurnal Trial Balance tidak diperlukan lagi, tetapi diganti dengan Financial Matrix ataupun comprehinsive financial statement yang muncul otomatis pada tiap transaksi. Konsep ini memberi kepastian bahwa sebuah transaksi dilakukan dengan akurat dan benar. Maka dari itu Comprehensive Financial Statement dapat diterbitkan sewaktu-waktu, meliputi Balance Sheet, Income Statement dan Equity Statement. (Fig. 19) 


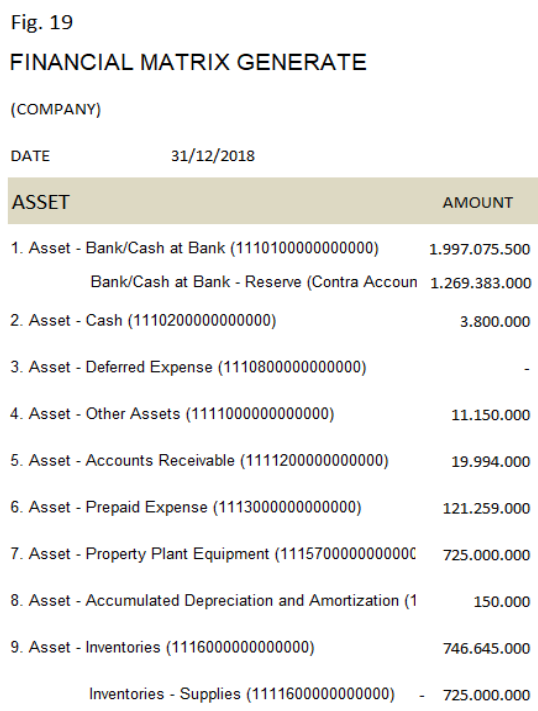

\begin{tabular}{|c|c|}
\hline LIABILITIY & AMOUNT \\
\hline \multicolumn{2}{|l|}{ 1. Liability - Notes Payable ( 1220000000000000$)$} \\
\hline 2. Liability - Unearned Revenue $(1220900000000000)$ & 1.166 .000 .000 \\
\hline 3. Liability - Accounts Payable $(1220100000000000)$ & 80.075 .000 \\
\hline 4. Liability - Tax Payable (1221000000000000) & 10.500 .000 \\
\hline \multicolumn{2}{|l|}{ 5. Liability - Bonds Payable (1221100000000000) } \\
\hline 6. Liability - Salaries and Wages Payable ( 1221200000000000$)$ & 4.500 .000 \\
\hline 7. Liability - Interest Payable $(1223000000000000)$ & 8.300 .000 \\
\hline 8. Liability - Warranty Payable (1224000000000000) & 8.00 \\
\hline \multicolumn{2}{|l|}{ 9. Liability - Third Party Accounts $(1225000000000000)$} \\
\hline Sub Total Liability & 1.269 .383 .000 \\
\hline EQUITY & AMOUNT \\
\hline 1. Equity - Owner's Capital (1330000000000000) & 1.750 .000 .000 \\
\hline 2. Equity - Share Capital-Ordinary $(1331100000000000)$ & \\
\hline 3. Equity - Retained Earnings (1333000000000000) & 101.000 \\
\hline 4. Equity - Capital Contributions ( 1339000000000000$)$ & \\
\hline 5. Equity - Dividends ( 1333200000000000$)$ & \\
\hline 6. Equity - Income Summary $(1335000000000000)$ & 1.014 .365 .500 \\
\hline 7. Equity - Drawings (Distributions) (1336000000000000) & \\
\hline 8. Equity - Reserve $(1337000000000000)$ & 175.000 \\
\hline 9. Equity - Treasury Stock (1336000000000000) & \\
\hline 10. Special Accounts $(3000000000000000)$ & 135.984 .000 \\
\hline Sub Total Equity & 2.900.073.500 \\
\hline TOTAL LIABILITIES AND EQUITY & 4.169.456.500 \\
\hline
\end{tabular}

EXPENSE AMOUNT

1. Expense - Labour \& Welfare Expenses (2259700000000000) $\quad 1.975 .000$

2. Expense - Supplies Expense (2263100000000000) $\quad 135.000 .000$

3. Expense - Insurance Expense (2272200000000000) $\quad 29.000 .000$

4. Expense - Cost Of Goods Sold (2251000000000000) 237.500.000

5. Expense - Cost Of Service Sold (2251200000000000) $\quad 4.750 .000$

6. Expense - Salaries and Wages Expense (2272600000000000) $\quad 10.500 .000$

7. Expense - Depreciation Expense (2271100000000000) 150.000

8. Expense - Interest Expense $(2290500000000000) \quad 16.300 .000$

9. Expense - Purchase Returns and Allowances (Contra Account) (225400001- 11.500.000

10. Expense - Inventory Adjustment (2253000000000000) 3.250 .000

11. Expense - Cost of Account Receivable (2255000000000000) 450.000

12. Expense - Bad Debt Adjustment (2258000000000000) $\quad 175.000$

13. Expense - Tax Expense (2259000000000000) 31.500 .000

14. Expense - Business Expenses (2250000000000000) 2.250 .000

15. Expense - Provision $(2257000000000000) \quad 10.500 .000$

$\begin{array}{lr}\text { TOTAL EXPENSE } & 471.800 .000\end{array}$ 


\section{REFERENCE}

[1] Kontributor Wikipedia, Braille, Wikipedia, Ensiklopedia Bebas, 4 Juni 2018, https://id.wikipedia.org/wiki/Braille

[2] Martin Childs, John McCarthy: Computer scientist known as the father of AI, The Independent, London - UK, 1 November 2011,

https://www.independent.co.uk/news/obituaries/john-mccarthy-computer-scientist-known-asthe-father-of-ai-6255307.html

[3] Investopedia Academy, International Financial Reporting Standards - IFRS, USA, 2018, https://www.investopedia.com/terms/i/ifrs.asp

[4] Orrin Woodward, The Financial Matrix, USA, 2017, http://orrinwoodwardblog.com/thefinancial-matrix/ 